PRZEGLĄD BIBLIOTECZNY 2019 z. 4

PL ISSN 0033-202X

\title{
ANNA WAŁEK
}

The Library of Gdansk University of Technology

e-mail: anna.walek@pg.edu.pl

ORCID: 0000-0001-8782-013X

\section{DATA LIBRARIAN AND DATA STEWARD - NEW TASKS AND RESPONSIBILITIES OF ACADEMIC LIBRARIES IN THE CONTEXT OF OPEN RESEARCH DATA IMPLEMENTATION IN POLAND}

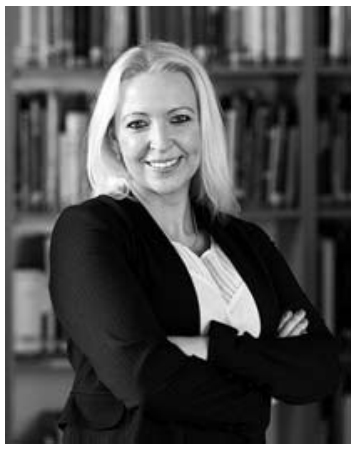

Anna Wałek, dr, Director of the Library of the Gdańsk University of Technology, is an expert in the field of open access to scientific resources, digital libraries as well as organization and management of a scientific library. A graduate of the Institute of Information and Library Science at the University of Wroclaw, where she obtained a PhD in the field of Library and Information Science in 2013. Member of international associations and expert groups. Manager and coordinator of projects implemented from EU funds. Author of scientific publications, in particular about digital libraries, Open Access and innovations in scientific libraries.

KEYWORDS: Academic libraries. Data librarian. Data steward. Open Access. Open Research Data. Plan S, Research Data Services. Open policy

ABSTRACT: Thesis/Objective - The policy of Open Access (OA) for researching resources in Europe has been implemented for more than 10 years. The first recommendations concerning providing $\mathrm{OA}$ to scientific materials were defined during the implementation of the 7th Framework Programme. Introducing another set of recommendations concerning OA to research data was the next stage. The recommendations were transformed into obligations under the Horizon 2020 Programme. In 2018, research-funding institutions were associated in the Plan $S$ document issued by CoalitionS, which aims to ac- 
celerate the transition to full and immediate OA to publications from publicly funded research until January 2021. Academic libraries have always been pioneers in implementing OA to research, creating the necessary tools (platforms and repositories), and preparing training workshops for researchers. OA policy implementation, including both access to research resources and data, is accelerating. That is why the role of academic libraries and academic librarians has become crucial. The article presents how library services and the scope of tasks of their employees change in connection with the introduction of open access policies for research data in Poland. Research methods - A critical review of the literature was used to analyse the content of foreign and Polish LIS literature published in the years 2009-2019. In addition, official documents issued by the European Commission were analysed, as well as websites devoted to Open Research Data (ORD). Results and conclusions - Some new specialisations in librarianship have been introduced - e.g. a data librarian who is responsible not only for academic staff training sessions on Open Research Data, but also for assistance for research teams in the field of data management and data curation. In the future, academic libraries will be responsible for coordinating the work of data stewards responsible for supporting the process of research data creating and managing at university departments and in research teams.

\section{EUROPEAN OPEN SCIENCE POLICY}

In 2006, the European Commission (EC) recommended that scientific publications financed from EU funding should be available in Open Access (OA) repositories. In August 2008 the pilot OA program under the 7th Framework Program (FP7) was launched. Beneficiaries receiving funding in seven areas (including energy, health, humanities, and social sciences) were required to publish the results of research in open repositories, no later than 6 or 12 months after the end of the research, depending on the field they represented. In the document Open Access Pilot in 7FP, the EC indicates that publishing research results in Open Access model not only increases the visibility of scientific papers, which increases the citability of publications and their impact on science, but also reduces the likelihood of duplication of research which is of economic importance (European Commission, 2008).

In subsequent years, the policy was developed. Further analyses and recommendations were created. European Open Research Data policy was developed in July 2012. The EC published the communication Towards better access to scientific information (European Commission, 2012a) and recommendations (European Commission, 2012b) regarding the implementation of Open Access policy in relation to research data, including Horizon 2020. It was agreed that Horizon 2020 would have a pilot program on the sharing of research data. This initiative is part of a broad project called "The European Research Area".

In October 2013 EC published a report on public consultation on Open Research Data (European Commission, 2013) and two years later adopted 
the Digital Single Markets Strategy (European Commission, 2015). Another important step was to set up a cloud for research data - The European Open Science Cloud, an infrastructure which is supposed to provide web hosting, make ORD available to European institutions, and strengthen the economic potential of the European Union. It became crucial to increase Europe's competitiveness through development and implementation of ORD policy and innovative solutions for research data services and infrastructure.

An important step towards strengthening this policy and monitoring its progress was to set up an expert committee, "Open Science Policy Platform”, in 2016 to monitor the implementation of Open Science recommendations. The result of further activities was the publication of the instructions FAIR Data Management in Horizon 2020 (European Commission Directorate General for Research \& Innovation, 2016) in 2016, and the FAIR Open Research Data report in January of 2017 (European Commission, 2017).

The European Commission recommended member states of the European Union to develop their own national Open Access policies. In Central and Eastern European countries, providing Open Access to results of scientific research takes place mainly on a voluntary basis and is not a common practice. In other countries, e.g. the United Kingdom, a national OA mandate has been implemented, while in Germany there are different legal solutions concerning OA in each state of the country. Consequently, the degree of involvement in implanting OA at various universities across the European Community varies significantly (SPARC Europe, 2018).

\section{POLISH OPEN SCIENCE POLICY}

The idea of Open Science reached Poland with some delay. Although libraries had previously published publications in Open Access and scientists shared preprints of their publications in repositories, the first official document that referred to Open Access was the 2017 statement on the position of the rectors of Polish universities. This was the "Resolution on open access to scientific publications" (KRASP, 2007). Public discussion on this topic returned six years later when the joint body of the rectors' conference and the presidium of the Polish Academy of Sciences referred in their next position paper to "The Amsterdam call for action" (KRASP, PAN, 2013).

In 2014, the Open Science Platform located at the University of Warsaw prepared a report, titled Open Science in Poland (Szprot, et. al., 2014), describing the need to implement open access to scientific results, and a year later, on October, 2015 the Ministry of Science and Higher Education issued recommendations regarding the introduction of Open Access contained in the document entitled Directions of development of open access 
to publications and research results in Poland (MNiSW, 2015). This document has the character of recommendations regarding the introduction of open access by research funding entities, scientific units, universities, and publishers, including publishers of scientific journals.

In its website, the Ministry has placed a special subpage devoted to Open Science, containing materials regarding Open Access as well as, among others, an Open Access policy template. The Ministry emphasizes that it is scientific institutions, including universities, that should implement openness policies.

\section{PLAN S}

Plan $S$ is an initiative for Open Access research publishing that was launched in September 2018. The plan is supported by cOAlition S, an international consortium of research funders.

It requires that, from 2021, scientific publications that result from research funded by public grants must be published in compliant Open Access journals or platforms (Science Europe, 2019).

One of the claims says that such research output should be published in fully open journals, and not within hybrid OA models.

Plan $S$ also enables policy implementation through the so-called repository route, although this is not a promoted form of policy implementation. In accordance with Plan S, the author or the author's institution shall retain their copyright.

Licenses to publish that are granted to a publisher must allow the author/institution to deposit an appropriate version of the article in the repository. One of the signatories of Plan $S$ is the Polish National Science Centre (NSC; Polish: Narodowe Centrum Nauki - NCN).

\section{POLISH NATIONAL SCIENCE CENTRE OPEN POLICY}

Recently, the NSC has been introducing Open Access Policy in various ways and signals the need to implement openness in science. Among other things, the Plan of activities for 2019 highlights the need in the following way: "An important task for the Centre in 2019 will be the implementation of Open Access policy, especially in the context of what is called Plan S and data management in research projects. NCN is one of the founders of Coalition S, and recently signed the San Francisco Declaration (DORA) (...)" (NCN, 2018).

Another important event was the publication of the NSC Director's letter to the Polish scientific community in April 2019, emphasizing the need to provide open access to research data: "Having the above in mind, to- 
gether with other research funding agencies associated in Science Europe, we have taken actions to develop common European guidelines for the management of scientific data and how to share them in what is called open access (...)" (Błocki, 2019).

In June 2019, a call for applications for funding of subsequent NSC grants was announced. The introduction of the short data management plan to the grant application was a novelty for researchers applying for the NSC's funding.

\section{DATA MANAGEMENT PLAN (DMP)}

Some funding bodies have defined requirements that plans for managing the data produced during a research project should be included in grant proposals. These plans show how research data will be collected, organized, managed, and preserved during the project and after its completion. What such a plan looks like depends on the specificity and conditions of the project. In general, these plans require a description of the data that will be produced or used, formats, metadata standards that will be used to store and organize data, the "how" and "where" of the data storage and accessibility.

The NSC's data management plan includes five categories of questions that must be answered by researchers submitting grant applications:

1. Data description and collection or re-use of existing data

1.1. How will new data be collected or produced and/or how will existing data be re-used?

1.2. What data will be collected or produced (for example what kinds, formats, and volumes)?

2. Documentation and data quality

2.1. What metadata and documentation (for example methodology or data collection and way of organising data) will accompany data?

2.2. What data quality control measures will be used?

3. Storage and backup during the research process

3.1. How will data and metadata be stored and backed up during the research process?

3.2. How will data security and protection of sensitive data be taken care of during the research?

4. Legal requirements, codes of conduct

4.1. If personal data are processed, how will compliance with legislation on personal data and on data security be ensured?

4.2. How will other legal issues, such as intellectual property rights and ownership, be managed? What legislation is applicable? 
5. Data sharing and long-term preservation

5.1. How and when will data be shared? Are there possible restrictions to data sharing or reasons for embargo?

5.2. How will data for preservation be selected, and where will data be preserved long term (for example a data repository or archive)?

5.3. What methods or software tools will be needed to access and use the data?

5.4. How will the application of a unique and persistent identifier (such us a Digital Object Identifier (DOI)) to each data set be ensured?

6. Data management responsibilities and resources

6.1. Who will be responsible for data management (i.e. data steward)?

6.2. What resources will be dedicated to data management and ensuring that data will be FAIR? (NSC, 2019).

\section{OPEN RESEARCH DATA}

There are many definitions of research data. One of them was published on the University College London (UCL) Blog in 2015. "Research data are the original sources or material that you have created or collected to conduct your research project. They can be digital or non-digital. The response to your research question is based on the analysis of these research data" (UCL, 2015).

According to the guidelines “(...) NSC understands 'data' to be both collected, unprocessed data as well as analyzed, generated data. Under this all forms are conceivable; digital and non-digital (for example samples, completed questionnaires, sound recordings, etc.)" (NSC, 2019).

More and more research data is born in a digital form, although physical forms are still common within some fields of study. Researchers must keep track of both kinds of data usage simultaneously. Obviously research projects are today producing huge sets of data that would be impossible to manage without the aid of computers to process them. There are generally two types of data: qualitative (measures of 'types' and may be represented by a name, symbol, or a number code. Qualitative data are data about categorical variables) and quantitative (measures of values or counts, expressed as numbers; data about numeric variables). Most researchers usually gather both kinds of data in their research (Krier, Strasser, 2014). Undoubtedly, we can find also other types of data categorization. For example, we can distinguish primary data (original data that arise from a particular experiment or observation), which are gathered and maintained by researchers, and secondary data, often used by researchers 
but originally created by someone else (Krier, Strasser, 2014). Both primary and secondary data can take many forms, for example: observational data - data that have been gathered from observing a particular phenomenon, and experimental data - in contrast - data that have been derived from controlled, randomized experiments. Data still can be produced by researchers themselves, e.g. taking notes or describing observations, but more often, data are gathered with the use of computers, sensors, and other monitoring tools. These tools produce far larger data sets for researchers to collect or analyse (Krier, Strasser, 2014).

\section{THE ROLE OF THE ACADEMIC LIBRARY}

Greater collaboration among researchers, engineers, and computer scientists became a fact in all fields of study, and librarians are being brought to the table to contribute needed expertise in data management, curation, and preservation. Along with the development of Open Access, librarians became engaged in the process of depositing digital publications in OA repositories. They were developing their competencies for creating OA policies, as well as developing institutional repositories services (Wałek, 2018).

The next step for academic librarians was to engage with research data management processes and curation needs. As mentioned before, funding agencies like the Polish NSC and a number of research institutions began to implement data management policies. At the same time scientific journals recommended sharing data sets, which allows researchers to verify the research results included in scientific articles. Nowadays librarians have to face yet another challenge. They are obliged to adjust their services to suit new needs and navigate changes that are going on in a complex research and publication world. In the guidelines for potential grant recipients referred to above, the NSC emphasizes the advisory role of libraries: "For the completion of the section please contact the library/intended repository/ICT Department of your institute or university. They can help you with the completion of the data section" (NSC, 2019).

At the present time librarians are supposed to specialize in new areas and a new specialization has been created - a data librarian. The responsibilities of the new type of librarian embrace new skills and knowledge, and require librarians to become actively engaged in the research process (Wałek, 2018).

\section{DATA LIFECYCLE}

There are two ways to think about the lifecycle of data. We can consider it from a researcher's perspective and from a curator's perspective. 
The first one, "Research data lifecycle" (UK Data Archive, 2018), created by the UK Data Archive, could be useful if you think about the data from a researcher's perspective. It covers the lifespan of research data from the moment of its creation through the reuse of the data. The sequential steps of this lifecycle are: creating data, processing data, analysing data, preserving data, giving access to data, and reusing data.

On the other hand, the Digital Curation Centre has created a "Curation lifecycle model" (Digital Curation Centre, 2018) that lays out all the steps in data curation from an archivist's or a curator's perspective. A short definition of data curation has been included in the LITA Guide Data Management for Libraries: "Data curation is the management of data once it has been selected for preservation and long-term storage" (Krier, Strasser, 2014).

The sequential steps of the curation lifecycle are: creating or receiving data, appraising and selecting data, ingesting, performing preservation actions, storing data, accessing data for use and reuse, and transforming data.

Many researchers and librarians are involved at various stages of the data lifecycle, both during the research process and during the curation process.

Libraries have begun stepping in to provide assistance in research data management. Some librarians treated this new duty as an opportunity for professional growth, while others decided to learn new skills because of external pressure. As Laura Krier has said "in any case, librarians have a great opportunity to expand our services in ways that can benefit faculty, build stronger relationships between libraries and research communities, and continue to play a role in the preservation of scholarly communication".

\section{RESEARCH DATA SERVICES}

"Research data services are services that address the full data lifecycle, including the data management plan, digital curation (selection, preservation, maintenance, and archiving), and metadata creation and conversion" (Tenopir, Sandusky, Allard and Birch, 2012). Research data are becoming more and more important for researchers who are starting to appreciate the benefits of sharing data or are obliged to provide open access to their research results by funding providers. Scientists are beginning to see the advantage in reusing data sets. This has been confirmed by the results of the research conducted by Digital Science-Figshare. "The State of Open Data Report 2016" (Treadway, Hahnel, et. al. 2016) examined global attitudes towards Open Research Data (ORD). It included survey results of more than 2,000 respondents. The key finding was, that ORD had become more embedded in the research community. $60 \%$ of the survey re- 
spondents were aware of the equal importance of quoting data sets and quoting research articles. More than $50 \%$ of the survey respondents agreed that they would need more assistance in data disseminating, choosing the relevant licenses, and managing research data. The Report also shows how significant research data is, medical data in particular, in the context of rescuing human life, producing new drugs, and discovering innovative treatment options (Wałek, 2018).

Another survey on ORD conducted by Digital Science-Figshare in 2017 - “The State of Open Data Report 2017" (Digital Science et. al., 2017) - confirmed the results of the previous Report. "The State of Open Data Report 2017 " showed the growth of the number of respondents $(2,300)$ from all over the world. $82 \%$ of the survey respondents recognized the necessity of research data dissemination (10\% growth in the number of respondents supporting ORD dissemination in comparison with 2016). The number of survey respondents who would like to reuse research data also increased by $10 \%$, reaching $80 \%$. All the respondents emphasized the lack of proper education and support for research data management and dissemination. The survey shows that researchers expect support in this respect from universities they are affiliated with. According to the survey results, what also encourages the faculty to share their research data is the increased number of citations for their papers (Wałek, 2018).

Another source - the Council in Library and Information Resources report "The Problem of Data" - notes that researchers "understand that poor data management can be costly to their research and that access to greater technical expertise, through either a consultant or additional training, would be useful for their work" (Jahnke, Asher, Keralis, 2012). According to the report only a few researchers are happy with their own data management practices. They report as a problem the fact that they do not have time for the administrative and organizational work and that they have never received explicit training in data management practices (Wałek, 2018).

\section{DATA LIBRARIAN}

The field of data librarianship has not been fully defined. According to LIBER's "Job Description Marketplace" a data librarian is an expert on research data management, description, archiving, and dissemination. The data librarian has to develop technical expertise on practical solutions of data management, archiving, and dissemination, and on data mining and visualization. Data librarians help design services for researchers and research units on data management. Librarians use their technical expertise to train and support researchers with their data from defining their needs to proposing practical solutions (LIBER, 2018). 
For a number of years the role of libraries and librarians in data management and data curation processes has been discussed. The aim of surveys conducted in various countries was to define the data librarians' professional identification, educational background, experience, knowledge, skills, and qualities that would allow them to perform the new duties in an effective manner and in line with new expectations. Additionally, various guides and tutorials were created, enabling librarians to improve their qualifications in this field.

The results of the surveys displayed the need for a set of particular competencies and skills that were essential for librarians specialising in data management and data curation. The results of Kennan's survey presented during the IFLA Conference in Columbus (2016) concurred with the earlier findings of Kellam (Kellam, 2011) and Tenopir (Tenopir, Hughes, et. al., 2015) and later of Mizzy and Hayslett (Mizzy, Hayslett, 2016).

In 2015 Mary Anne Kennan conducted a survey among data managers, librarians, and their supervisors and employers, to investigate key knowledge and skills for new professionals coming into data practice in universities and other scientific and research organizations. The results of these studies were announced during the IFLA conference in Columbus in 2016.

The survey's participants reported that the employment pattern differs across organizations. They worked in libraries and other information departments such as IT, and in research offices. There was also a huge range of job titles (e.g. Data Librarian, Data Manager, Data Specialist) used by data specialists and curators. As Kennan reported, almost all the employers indicated that the major set of skills they required, or that they were looking for in librarians and other data specialists, were more generic than field specific and these could be labelled as interpersonal skills and behavioural characteristics. It was also mentioned that subject specialty in specific areas would be encouraged. The second most frequently mentioned requirement was knowledge in the data domain and related skills. Knowledge and skills related to facilitate data sharing, linked data, data management lifecycle, quality control, data processing, data management planning, and the ability to understand and support data storage requests were mentioned as crucial for the development of data librarianship. It is worth emphasising that data professionals should be aware of the legal and regulatory frameworks relevant to data, as well as ethics, copyright, and creative commons issues. Almost every participant mentioned the importance of knowledge about and skills in applying metadata, metadata standards, ontologies, and structured information, as well as possessing data mapping, cataloguing, and harvesting competencies. A number of IT skills were also recognised as significant factors. Data specialists should have a sufficient understanding of IT to be able to communica- 
te with both IT specialists and researchers. Taking into account the education and previous experience of data professionals, it is apparent that most of them were librarians, some with prior qualifications in IT. Another group of librarians working as data professionals was made up of people who simply had some practical experience in IT without a college degree. These people had usually learned data specific knowledge and skills "on the job", working in the data management space in academic libraries or through additional targeted professional development (Wałek, 2018).

What is also important, after surveying and interviewing a cross section of librarians supporting scientific research authors conducted by Mizzy and Hayslett (Mizzy, Hayslett, 2016) - the authors concluded that there is no one path to data librarianship. Some people start their professional careers in science and become librarians later, and some others start in librarianship and specialize in science over the course of their professional careers. The authors prepared interview questions based on Kellam's survey about "experiences becoming and being data librarians" (Kellam, 2011).

\section{DATA STEWARD}

A data steward is a slightly different position than a data librarian. Data stewards are directly responsible for data management and for the support of data life cycle processes. The data steward's role is essentially to support the user community. They are responsible for collecting, collating, and evaluating issues and problems with data. Typically, data stewards are assigned either according to subject areas, functions, or business processes. As data stewards are accountable for the quality of the data, they must also manage standard business definitions and metadata for critical data elements. They also oversee the enterprise data quality standards, including the data rules associated with the data sets. Essentially, a data steward is the conduit for communicating issues associated with the data life cycle - the creation, modification, sharing, reuse, retention, and backup of data. If any issues emerge regarding the conformance of data to the defined policies over the lifetime of the data, it is the steward's responsibility to resolve them (Loshin, 2009).

\section{CONCLUSION}

Libraries' services provided to researchers and research institutions in order to assist them with the research data management process are evolving. The new duties of libraries differ from the previous tasks they have been responsible for so far, and libraries must adapt to the new conditions 
to be up to date with services provided in data managing. Librarians have become a part of the research process from the very beginning of the data lifecycle. Their knowledge and engagement are essential from a very early moment of DMP creation through collecting, describing, preserving, and curating data. Additionally, librarians will also be responsible for ensuring that data sets prepared by research teams are properly used and cited. The new tasks related to research data management pose different challenges for librarians that they will have to live up to.

An important task for academic libraries and new specialists employed in them - data librarians - will be close cooperation with research teams and other specialists dealing with data, such as data stewards.

Following the example of some universities in other countries, such as Cambridge or Delft, multidisciplinary teams should be created in Polish universities. The teams' duties will be to support researchers in the tasks they face, for example those due to the emerging policy of open data. The future role of the academic library will be to coordinate the work of such multi-task teams responsible for creating repository tools. The role will also include developing institutional research data management services, and providing research data management advisory and training services. These new tasks and activities will entail the need to work collaboratively with other stakeholders to ensure that future research is supported effectively.

\section{REFERENCES}

Błocki, Zbigniew (2019). Pismo dyrektora NCN w sprawie zarzadzania danymi naukowymi w projektach [accessed on: 11.11.2019]. Available on WWW: $<$ https://www. ncn.gov.pl/sites/default/files/pliki/2019_04_03_pismo_dyrektora_NCN_zarzadzanie_danymi_naukowymi.pdf $>$.

Del Rosso, Jim; Lampert, Cory (2013). So you want to be a digital librarian - what does that mean? [Electronic version]. In: J. D. Monson (ed.), Jump-start your career as a digital librarian: A LITA guide (pp. 3-19). Chicago, IL: American Library Association [accessed on: 17.11.2019] Available on WWW: <https://digitalcommons.ilr.cornell.edu/cgi/viewcontent.cgi?article=2013\&context=articles $>$.

Digital Curation Centre (2018). DCC Curation Lifecycle Model [accessed on: 17.11. 2019]. Available on WWW: <www.dcc.ac.uk/resources/curation-lifecycle-model>.

Digital Science, Hahnel, Mark; Treadway, Jon; Fane, Briony; Kiley, Robert; Peters, Dale; et al. (2017). The State of Open Data Report 2017. Figshare. Paper. [accessed on: 17.11.2019]. DOI: https://doi.org/10.6084/m9.figshare.5481187.v1.

European Commission (2008). Open Access Pilot in FP7 [accessed on: 13.11.2019]. Available on WWW: <https://ec.europa.eu/research/science-society/document_library/pdf_06/open-access-pilot_en.pdf $>$.

European Commission (2012a). Towards better access to scientific information: Boosting the benefits of public investments in research. Communication from the Com- 
mission to the European Parliament, the Council, the Economic and Social Committee and the Committee of the Regions, Brussels, 17.7.2012 COM(2012) 401 final, [accessed on: 17.11.2019]. Available on WWW: <https://ec.europa.eu/research/ science-society/document_library/pdf_06/era-communication-towards-betteraccess-to-scientific-information_en.pdf $>$.

European Commission (2012b). Commission Recommendation of 17.7.2012 on access to and preservation of scientific information $\{\operatorname{SWD}(2012) 221$ final $\}\{\operatorname{SWD}(2012)$ 222 final\} Brussels, 17.7.2012 C(2012) 4890 final, [accessed on: 17.11.2019]. Available on WWW: <https:/ec.europa.eu/digital-single-market/node/66216>.

European Commission (2013). Final Report of the European Commission Public Consultation on Open Research Data, [accessed on: 17.11.2019]. Available on WWW: $<$ https:/ec.europa.eu/digital-single-market/en/news/final-report-public-consultation-open-research-data>.

European Commission (2015). A Digital Single Market Strategy for Europe. Communication from the Commission to the European Parliament, the Council, the Economic and Social Committee and the Committee of the Regions, Brussels, 6.5.2015 $\operatorname{COM}(2015) 192$ final \{SWD(2015) 100 final\}, [accessed on: 17.11.2019]. Available on WWW: <https://eur-lex.europa.eu/legal-content/EN/TXT/?uri=celex:52015DC0192>.

European Commission (2017). Open Science Monitoring Impact Case Study - Data FAIRport, [accessed on: 17.11.2019]. Available on WWW: <https://ec.europa.eu/ research/openscience/pdf/monitor/fairport_case_study.pdf $>$.

European Commission Directorate General for Research \& Innovation (2016). H2020 Programme Guidelines on FAIR Data Management in Horizon 2020, Version 3.026 July 2016, [accessed on: 17.11.2019]. Available on WWW: <http://ec.europa.eu/research/participants/data/ref/h2020/grants_manual/hi/oa_pilot/h2020hi-oa-data-mgt_en.pdf $>$.

Jahnke, Lori; Asher, Andrew; Keralis, Spencer D.C. (2012). The Problem of Data (Washington, DC: Council on Library and Information Resources), [accessed on: 17.11.2019]. Available on WWW: <http://www.clir.org/wp-content/uploads/sites/6/pub154.pdf>.

Kellam, Lynda M. (2011). Data librarianship: a day in the life, In: Numeric Data Services and Sources for the General Reference Librarian, ed. L. Kellam and K. Peter (Oxford: Chandos Publishing) pp. 151-160, [accessed on: 17.11.2019]. DOI: https://doi.org/10.1016/B978-1-84334-580-0.50005-5.

KRASP (2007). Uchwała Zgromadzenia Plenarnego KRASP z dnia 26 kwietnia 2007 r. $w$ sprawie powszechnego dostepu do publikacji naukowych [accessed on: 13.11 . 2019]. Available on WWW:<https://arch.krasp.org.pl/pliki/28349c3ea96fd8f16b f5f3b026678fb9.pdf>.

KRASP, PAN (2013). Stanowisko Prezydium KRASP i Prezydium PAN z dnia 5 lipca 2013 r. w sprawie zasad otwartego dostępu do treści publikacji naukowych i edukacyjnych [accessed on: 13.11.2019]. Available on WWW: <http://krasp.strony. uw.edu.pl/wp-content/uploads/sites/2/2013/07/krasp_pan_oa.pdf >.

Krier, Laura; Strasser Carly A. (2014). Data Management for Libraries. A LITA Guide, Chicago, ALA Tech Source

LIBER Europe (2018). Data librarian, expert on research data management, description, archiving and dissemination [accessed on: 13.11.2019]. Available on 
WWW: <https://libereurope.eu/blog/2018/05/14/data- librarian-expert-on-research-data-management/>.

Loshin, David (2009). Master Data Management, The MK/OMG Press, pp. 67-86 [accessed on: 13.11.2019]. DOI https://doi.org/10.1016/B978-0-12-374225-4.00004-7.

Mizzy, Danianne; Hayslett, Michele (2016). Data Librarianship: A Day in the LifeScience Edition In: Databrarinaship. The Academic Data Librarian in Theory and Practice, Chapter 21, ACRL, Chicago, Illinois, pp. 335-354.

MNiSW (2015). Kierunki rozwoju otwartego dostępu do publikacji i wyników badań naukowych $w$ Polsce [accessed on: 11.11.2019]. Available on WWW: <https://www. gov.pl/attachment/d9d096ef-0c73-4a48-9c5a-b2cb808447e8>.

NCN (2018). Plan dziatalności Narodowego Centrum Nauki. Rok 2019 [accessed on: 13.11.2019]. Available on WWW: <https://www.ncn.gov.pl/userfiles/file/inne_ dokumenty/2019_plan_dzialalnosci_ncn.pdf>.

NSC (2019). Guidelines for applicants to complete the Data Management Plan form in the proposal [accessed on: 13.11.2019]. Available on WWW: <https://ncn.gov. $\mathrm{pl} /$ sites/default/files/pliki/regulaminy/wytyczne_zarzadzanie_danymi_ang. pdf $>$.

Ohaji, Isaac Kenechukwu (2016). Research Data Management: An Exploration of the Data Librarian Role in New Zealand Research Organisations, Victoria University of Wellington 2016 (PhD thesis), [accessed on: 17.11.2019]. Available on WWW: $<$ http://researcharchive.vuw.ac.nz/handle/10063/5657>.

Science Europe AISBL (2019). Plan S. Making full and immediate Open Access a reality [accessed on: 13.11.2019]. Available on WWW: <https://www.coalition-s. org/>.

SPARC Europe (2018). An Analysis of Open Data and Open Science v 2.1 (January 2018). [accessed on: 11.11.2019]. Available on WWW: $<$ https://sparceurope.org/ download/2285/>.

Szprot Jakub red. (2014). Otwarta nauka w Polsce 2014. Diagnoza [accessed on: 13.11. 2019]. Available on WWW: <http://pon.edu.pl/images/plon_publications/files/13_Otwarta\%20nauka\%20w\%20Polsce\%202014_Diagnoza.pdf $>$.

Tenopir, Carol et al., (2017). Research Data Services in European Academic Research Libraries. LIBER Quarterly. 27(1), pp. 23-44, [accessed on: 11.11.2019]. DOI: http://doi.org/10.18352/lq.10180.

Tenopir, Carol; Birch, Ben; Allard, Suzie (2012). Academic libraries and research data services: Current practices and plans for the future [White paper]. Association of College and Research Libraries, [accessed on: 11.11.2019]. Available on WWW: $<$ http://www.ala.org/acrl/sites/ala.org.acrl/files/content/publications/whitepapers/Tenopir_Birch_Allard.pdf >.

Tenopir, Carol; Hughes, Dare; Allard, Suzie; Frame, Mike; Birch, Ben; Baird, Lynn; Lundeen, Andrew (2015). Research data services in academic libraries: Data intensive roles for the future? Journal of eScience Librarianship, 4(2) [accessed on: 12.11.2019]. Available on WWW: <http://dx.doi.org/10.7191/jeslib.2015.1085>.

Tenopir, Carol; Sandusky, Robert J.; Allard, Suzic; Birch, Ben (2012). Academic librarians and research data services: Preparation and attitudes (Session 116). Paper presented at IFLA World Library and Information Congress, Helsinki, Finland [accessed on: 11.11.2019]. Available on WWW: $<$ http://conference.ifla.org/pastwlic/2012/116-tenopir- en.pdf $>$. 
Treadway, Jon; Hahnel, Mark; Leonelli, Sabina; Penny, Dan; Groenewegen, David; Miyairi, Nabuko; Hayashi, Kazuhiro; O’Donnell, Daniel; Digital Science and Hook, Daniel (2016). The State of Open Data Report. figshare. Paper. [accessed on: 13.11.2019]. DOI: https://doi.org/10.6084/m9.figshare.4036398.v1.

UCL (2015). What are research data? In Research Data Management Blog 15 September 2015 [accessed on: 13.11.2019]. Available on WWW: <https://blogs.ucl.ac.uk/ $\mathrm{rdm} / 2015 / 09 /$ what-is-research-data/>.

UK Data Archive (2018). Research Data Lifecycle, [accessed on: 13.11.2019]. Available on WWW: <http://data-archive.ac.uk/create-manage/life-cycle>.

Wałek, Anna (2018). Is data management a new "digitisation"? A change of the role of librarians in the context of changing academic libraries' tasks, IFLA WLIC 2018 Kuala Lumpur, Malaysia - Transform Libraries, Transform Societies/ Hague: IFLA, 2018, p.1-11 [accessed on: 17.11.2019]. Available on WWW: <https:// mostwiedzy.pl/pl/publication/download/1/is-data-management-a-new-digitisation-a-change-of-the-role-of-librarians-in-the-context-of-changing-_30244. pdf $>$.

Artykut w wersji poprawionej wptynat do Redakcji 30 listopada 2019 r.

ANNA WAŁEK

Biblioteka Politechniki Gdańskiej

e-mail: anna.walek@pg.edu.pl

ORCID: 0000-0001-8782-013X

\section{DATA LIBRARIAN I DATA STEWARD - NOWE ZADANIA BIBLIOTEK AKADEMICKICH W KONTEKŚCIE WDRAŻANIA POLITYKI OTWARTEGO DOSTĘPU W POLSCE}

SŁOWA KLUCZOWE: Biblioteki akademickie. Data Librarian. Data steward. Kustosz danych. Open Access. Otwarte Dane Badawcze. Plan S. Otwarty mandat. Zarządzanie danymi

ABSTRAKT: Tezy/cel - Polityka otwartego dostępu do zasobów nauki na poziomie europejskim wdrażana jest od ponad 10 lat. Pierwsze zalecenia, dotyczące udostępniania publikacji w modelu Open Access pojawiły się już w trakcie realizacji 7 Programu Ramowego. Kolejnym krokiem było wprowadzenie zaleceń w zakresie otwartego udostępniania danych badawczych. Zalecenia te przekształciły się $\mathrm{w}$ obowiązek $\mathrm{w}$ ramach programu Horyzont 2020. W 2018 r. instytucje finansujące badania naukowe, zrzeszone w CoalitionS, 
wydały dokument, nazywany PlanemS, który zakłada wprowadzenie pełnej otwartości do wyników badań naukowych finansowanych ze środków publicznych od stycznia 2021 roku. Jednym z sygnatariuszy porozumienia było polskie Narodowe Centrum Nauki. Biblioteki akademickie zawsze były pionierami jeśli chodzi o wdrażanie zasad otwartości, tworzenie narzędzi w postaci platform i repozytoriów, a także prowadzenie szkoleń dla kadry naukowej. Również w przypadku coraz bardziej intensywnego wdrażania polityki otwartego dostępu, w tym do danych badawczych, rola bibliotek akademickich i ich pracowników staje się kluczowa. Artykuł przedstawia w jaki sposób zmieniają się usługi biblioteczne i zadania bibliotekarzy w kontekście wdrażania polityki otwartego dostępu do danych badawczych w Polsce. Metoda - Zastosowano metodę analizy i krytyki piśmiennictwa. Analizie poddano literaturę polską i zagraniczną z zakresu bibliologii i informatologii, obejmującą lata 2009-2019. Przeanalizowano również oficjalne dokumenty opublikowane przez Komisję Europejska, dotyczące Otwartych Danych Badawczych w programach unijnych. Wnioski - Powstają nowe specjalizacje w bibliotekach naukowych, takie jak data librarian (bibliotekarz danych) czy data steward (kustosz danych), które odpowiadają nie tylko za szkolenia dla kadry naukowej z zagadnień dotyczących Otwartych Danych Badawczych, ale również zapewniają bezpośrednią pomoc w tym obszarze, świadczoną na rzecz zespołów badawczych w zakresie zarządzania danymi i opieki nad nimi. Biblioteki będą również w przyszłości odpowiadały za koordynowanie prac specjalistów wspierających proces tworzenia i zarządzania danymi na wydziałach i w zespołach badawczych - tzw. data stewards. 